\title{
Playing with Fire: The Medieval Judicial Ordeals and their Downfall
}

\author{
Aaron Larson \\ Ohio State University
}

\section{Introduction}

The Dialogue on Miracles, by Caesarius of Heisterbach, tells a story of a sinning fisherman who was known to have had sex out of wedlock multiple times with the same woman. The man knew his sin was well known across the town, and there were only two options; confess and marry the woman or go through a trial by ordeal and face God's judgment. The fisherman decided to go to the nearest priest and confess his sins. The priest applauded him for confessing and said that as long as he never sinned again, he would be able to carry the red-hot iron fearlessly. God would not punish the man, as his sins had already been stated. The man was acquitted. After many days the man was back on the water fishing. At one point he passed the woman's house with whom he had fornicated. He at once thought to get out of his boat and head over to the house. When he stuck his hand into the water with this thought in mind, the water immediately burned him, just as if he were holding the red-hot iron. ${ }^{1}$

This sermon story is just one of many examples of people being subjected to the trials by ordeal in medieval Europe. With Biblical origins, these trials sought out God's judgment in criminal matters. ${ }^{2}$ The unilateral ordeals are split into two main uses. Trial by fire, which was depicted in the previous sermon story, and trial by water which was the oldest form of the ordeal used in Europe. ${ }^{3}$ There were two forms, the hot water ordeal and the cold-water ordeal. ${ }^{4}$

\footnotetext{
${ }^{1}$ Caesarius of Heisterbach, The Dialogue of Miracles v. 2, ed. by G.G. Coulton and Eileen Power, (Broadway House: George Routledge \& Sons LTD. 1929): 202-03.

${ }^{2}$ The word of God in the Bible set out many instances of trials by Ordeal; it is depicted in Numbers 5:11-14, Genesis books 6-8/18-9, The Flood, The Parting of the Red Sea, and The Fires of Sodom and Gomorrah.

${ }^{3}$ Robert Bartlett, Trial by Fire and Water: The Medieval Judicial Ordeal, (Brattleboro: Echo Point Books and Media LLC, 2014): 8.

${ }^{4}$ Translations and Reprints from the Original Sources of European History, vol IV, no. 4 (Philadelphia: The Department of History of the University of Pennsylvania, 1897), 7-9. This prayer is from around the $12^{\text {th }}$ or $13^{\text {th }}$ century, so a little later in history than the Carolingian Empire, but the ideas are the same.
} 
Deciding between the water or fire ordeal all depended on the class and gender of the accused individuals. Trial by fire was generally saved for freemen and nobles, while villeins, or serfs, went to the cold water. ${ }^{5}$ The majority of people sent to the ordeals were lower class, and therefore trial by cold water was the most popular form of judgment. One might argue that trial by fire was a form of punishment in itself, so most went to the cold water as the hot iron was reserved for extreme cases as a semi-punishment. ${ }^{6}$ Seventeen percent of cases involved the hot iron, while the other eighty-three percent of trials by ordeal came down to the water, usually that of cold water. ${ }^{7}$ Just under two-thirds of those who underwent the ordeal passed freely. ${ }^{8}$

In modern times the ordeal seems to be irrational, but this was not actually the case. Laypeople in the Middle Ages thought the ordeals were rational, just like the idea of trial by jury is rational in the modern world. The trials were a way for the accused to have a second chance while standing trial with God. Ultimately, He would have the final say. Religion played an essential role in European's lives, so it is an easy assumption that they would want to model their trials after those that God had set out in the Bible. There was a strong feeling that mere human testimony was not enough evidence to convict someone of a crime. ${ }^{9}$ Instead, it was easier to turn their judgments over to the omnipotent and omniscient God. Although judges and priests considered human testimony and evidence, trial by ordeal was put into place where evidence was lacking, or miniscule.

In order to induce God's judgment, it was imperative that priests and judges practice the ordeals to the utmost perfection. ${ }^{10}$ If they did not, God would not be able to follow through with His 'promises' to the Europeans going through the trials. ${ }^{11}$ Although there were specific outlines for the procedures of the ordeals, it was hard to complete every small detail in the same way for each trial. Inaccuracies or missteps in the procedures of the ordeals could prove costly to the outcome. While God is omniscient, it was a major worry that he would not participate if the procedures were incorrect. This was a major worry of clerics in the Church. Was God ever really helping in the ordeals? Was it possible His judgment was not being induced with the best precision by lowly priests?

Trials by ordeal in medieval Europe provided a form of instruction for the laity. It was easy to see the trials as rational forms of justice in the Middle Ages, as it brought the word and judgments of God into play. God and religion had such a large impact on people's lives, it is easy

\footnotetext{
${ }^{5}$ Renulf De Glanvill, The Treatise on the Laws and Customs of the Realm of England, Commonly Called Glanvill, translated by G.D.G. Hall, (New York: Clarendon Press, 2002), 171-176.

${ }^{6}$ Paul R. Hyams, Kings, Lords, and Peasants in Medieval England: The Common Law of Villeinage in the Twelfth and Thirteenth Centuries, (Oxford: Oxford University Press, 1980): 156-157.

${ }^{7}$ Robert Bartlett, England Under the Norman and Angevin Kings, 1075-1225 (Oxford: Oxford University Press, 2002): 183 .

${ }^{8}$ Ibid, 183.

${ }^{9}$ Margaret Kerr, et al., "Cold Water and Hot Iron: Trial by Ordeal in England," The Journal of Interdisciplinary History, 22, 4 (1992), 573.

${ }^{10}$ Charles M. Radding, "Superstition to Science: Nature, Fortune and the Passing of the Medieval Ordeal," The American Historical Review, 84, no. 4 (1979), 956.

${ }^{11}$ Ibid.," 956.
} 
to see why there was support among the laypeople as they got to be as close to God's judgment as ever before. The bigger question is, what impact did the medieval Church have on the ordeals in Europe? Disagreements within the clergy of the Church started as early as the ninth century and lasted through their final days. Although there were a few exceptions, the consensus was that the ordeals were bad for the Church's reputation. The ordeals had Biblical origins, and people generally believed that the power of God was being displayed. Despite this the papacy and intellectuals were against the use of all ordeals in Europe.

By 1215 clerics in the Church had hit a breaking point. If the ordeals reinforced the authority of God and His Church within the Christian community, why were they so against them? Did the Church believe that God was being too easy on the accused and letting people go free? Did they believe He was being too harsh? Or did they believe God was not actually playing an impact in the ordeals at all? The culmination of the dislike and mistrust was finalized at the Fourth Lateran Council. It seemed like a sudden change in the medieval trials, but at the same time the decision was a buildup of centuries of discontent. Although it seems as if it was in the medieval clerics best interests to support the ordeals, they did not. Rather, what we discover is that a rift existed within the church over the function and viability of the ordeals. Although the ordeals had a basis in religion, ultimately it was religion that used its mistrust of the ordeals to tear down the basis of all early medieval legal tradition.

\section{Deeper Explanation of Ordeals}

The background of the trials by ordeal is simple; the workings behind them are not. Members of the medieval Church played a leading role in these trials, but they were not the only ones who partook in the long tradition. Ultimately, Church clerics were a minor part in the ordeals. A priest was the only requirement that the Church needed to supply for the ordeals to work efficiently. The rest would be executed by a script and God. Nonetheless, complications arise when trying to understand the ordeals in a simple sense. It was under the Carolingian Empire (c. 800-888) that the ordeals began to grow spontaneously. ${ }^{12}$ Charlemagne, King of the Carolingian Empire, proclaimed that the ordeal was to be used with no doubt given to God's abilities. ${ }^{13}$ This backed the credibility of the ordeal through royal command. Despite their slow downfall, it was during this period that the ordeals become more well-rounded, and the circumstances surrounding them became better outlined.

Although they had great support throughout Europe, the ordeals had a lot of limitation. They were only applied in certain circumstances, and against certain people or crimes. The ordeal was used only when there was little to no evidence. ${ }^{14}$ They acted as a buffer against immediate conviction of a crime. These trials were a defendant's second chance to prove they

\footnotetext{
${ }^{12}$ Bartlett, Fire and Water, 12.

${ }^{13}$ Ibid.

${ }^{14}$ Ibid., 26.
} 
were not guilty of the crime of which they were accused. The ordeals were the last chance given to those accused of a crime. ${ }^{15}$

Trial by water was used in two different instances: trial by hot water, and trial by cold water. Trials by hot water were the only ordeals mentioned in the written documents of the sixth, seventh, and eight centuries. ${ }^{16}$ While this could just be a coincidence, it is apparent that the hot water, or cauldron, ordeal was the only form in existence during the Carolingian period. ${ }^{17}$ The idea was that a cauldron filled with water was placed on an open flame. The water would be brought to a boil, signaling that it was hot to the touch. A Church priest would then bless a piece of metal, usually a ring, and drop it into the hot water.

Believed to be an invention under Charlemagne's reign ${ }^{18}$, trial by cold water came into use in the early years of the ninth century. Around this same time, high ranking Church officials began to speak out about the use of the ordeals. Emperors and popes looked to start regulating the use of the ordeals as they started to become more popular. ${ }^{19}$ Hincmar of Rheims described the cold-water ordeal as, " $[\mathrm{H}] \mathrm{e}$ who is to be examined by this judgment is cast into the water bound, and is drawn forth again bound." 20 The cold-water ordeals were more detailed than throwing the accused into water. Essentially the steps are the same as the trial by hot water, but the circumstances are changed. The accused was bound and blessed by a priest to induce God's judgment. They were then thrown into a body of water and watched to see if they float or sink. The former resulted in a guilty verdict, and the latter a verdict of innocence. ${ }^{21}$

Trial by fire, otherwise known as trial by hot iron, had similar origins to trial by hot water. The origins of the trial by fire ordeal come in 800 at the Council of Reisbach. ${ }^{22}$ Same as the other ordeals, a priest blessed the iron through prayer, essentially calling for God's help in the ordeal. The accused would walk a set number of paces while holding the iron, and have their hand bound for three days. After those three days had expired the hand was unwrapped and examined by either a priest, or another member of the court. If the hand showed any signs of healing, the accused was deemed innocent, but if the hand was festering, then God had found the accused guilty of their crime. ${ }^{23}$

There were a few instances in the Middle Ages in which the papacy or church councils attempted to restructure, or better outline the use of the ordeals. At the Assize of Clarendon in

\footnotetext{
${ }^{15}$ Bartlett, Fire and Water, 27. Although trials by battle are seen as another form of ordeal, they are considered bilateral, or having two parties in the civil suit. The unilateral only involve the accused, not the accuser.

${ }^{16}$ Bartlett, Fire and Water, 4.

${ }^{17}$ Ibid.

${ }^{18}$ Ibid., 9.

${ }^{19}$ Ibid., 11.

${ }^{20}$ Hincmar of Rheims, De Divortio Lotharii regis et Theutberga reginae (The Divorce of King Lothar and Queen Theutberga, c. 860), translated by Rachel Stone and Charles West, (Manchester: Manchester University Press, 2016).

${ }^{21}$ Bartlett, Fire and Water, 11.

${ }^{22}$ Ibid.

${ }^{23}$ Leeson, "Ordeals," 694.
} 
1166, canons 2 and 12 set out rules for the use of the water ordeals. ${ }^{24}$ Both canons deal with the idea of theft. If one is to be accused of theft and there is no evidence, then they are automatically to be taken to the trial by cold-water (c. 2) ${ }^{25}$ On the other hand, if the accused was found to be in possession of stolen goods, and he denied it in testimony, then he shall also go to the trial by cold-water (c. 12) ${ }^{26}$ Ten years later, at the Assize of Northampton in 1176, the Church council again attempted to reform the ordeals. This time the council outlined who should go through the ordeal of water, and what shall happen if he fails. ${ }^{27}$

In both cases, the King of England required the leading bishops in England to redraft the ideas surrounding English law. Both councils looked to reform the outline of the ordeals, as well as set strict punishments if the accused failed. The Assize of Northampton especially strengthened the English Church's stance on the ordeal by saying that those convicted of a crime were subject to losing a foot, as well as a hand, for their actions. ${ }^{28}$ It is peculiar, though, that less than forty years later, the members of the Fourth Lateran Council convened and outlawed the use of the ordeals, even as countries like England were attempting to strengthen their use of them.

Many questions still remain following our deeper understanding of the ordeals. If the highest power in the Middle Ages was God's judgment, then why did people not trust it to decide every trial? Why were there other forms of proof? These are some of the main questions that revolve around the ordeals and their eventual downfall. Priests of the medieval Church acted as some of the leading practitioners of the ordeals. They were required to be in attendance to bless the items being used and give a prayer. Despite this, the Church still spoke out against the use of the ordeals. The practice brought the priests and the Church fame and money. ${ }^{29}$ This still did not suffice to bring the Church to accept the ordeals for what they were. The overarching question is, why? Everything points to the Church accepting and perfecting the ordeals, but this was not the case. In the end, the ordeals fail because of the Church's insistence that they fall.

\section{Historiography}

Many modern historians have written on the impact the ordeals had on criminal justice. Very few have looked at the impact the prelates and canon lawyers had on the trials. The main focus in writing about the ordeals is trying to explain that they were less problematic than first perceived. Many of the thoughts and writings of theologians pertaining to the ordeals have yet to be translated from Latin into English. Letters from the popes condemning the ordeals before the Fourth Lateran Council are sparse, and even harder to get considering the language barrier. Some of the biggest Church documents released have been from Hincmar of Rheims, and Agobard of

\footnotetext{
${ }^{24}$ Assize of Clarendon in 1166.

25 Ibid., c. 2.

${ }^{26}$ Ibid., c. 12.

${ }^{27}$ Assize of Northampton in 1176, c. 1.

${ }^{28}$ Ibid.

${ }^{29}$ Bartlett, Fire and Water, 70.
} 
Lyons, yet they were just recently translated. ${ }^{30}$ Other major works are rarely cited as there is no modern interpretation of their meaning. One example of this is Peter the Chanter's writings on the ordeals which have yet to be translated as they do not prove useful to modern historians. ${ }^{31}$ Despite this, many historians still have published great and interesting works on the practices of the trials.

Possibly the most comprehensive research on the ordeals is Robert Bartlett's Trial by Fire and Water: The Medieval Judicial Ordeal. ${ }^{32}$ Bartlett covers the entire history of the unilateral ordeals, from beginning to end. Although he does cite the major theologians and their writings, much of Bartlett's book deals with the legal history. The ordeals played a significant impact in European society. Bartlett calls the end of the ordeals a "social change," alluding to the fact that it was a work of the people, and not the Church officials, that brought in the era of trial by jury. ${ }^{33}$ The theologians in the medieval Church had to stumble around for centuries until they found a suitable replacement for the ordeals.

The subtitle of Bartlett's book is the key to understanding his take on the ordeals. He calls it 'the Medieval Judicial Ordeal,' which excludes the theologians in the Church from all responsibility. Bartlett does look at clerical interests regarding the ordeals in his chapter, "The End of the Ordeal: Explanations in Terms of Belief." ${ }^{34}$ Bartlett does not expand on the ideas as to why the papacy and church councils completely opposed the practice. While the ordeals were not ecclesiastical trials, Christianity influenced the practice of the ordeals without any action from the Church itself. Bartlett's main argument throughout his book is that the downfall of the ordeals was a result of a call for social change outside the realms of the clerics. He takes a look at the Fourth Lateran Council, but holds the belief that the use of the ordeals was completely outdated by $1215 .{ }^{35}$ Although Bartlett is one of the leading scholars on the ordeals, he tends to omit, or speak very little on the ecclesiastical downfalls concerning the ordeals.

Another key scholar in this area of legal history is Charles Radding. ${ }^{36}$ Although he does introduce more arguments of the impact of God and the clerics, Radding tends to take some more controversial views. In a sense, the reader could see Radding's views as anti-Catholic. The bulk of his writing deals with 'superstition' in the ordeals. Superstition is too weak of a word to describe the Church officials' views of the ordeals. The papacy and church councils knew the ordeals were problematic. They were not at all superstitious of the practices.

\footnotetext{
${ }^{30}$ Hincmar of Rheims, De Divortio, was translated by two English researching professors, Rachel Stone and Charles West, in 2016. Agobard of Lyons, De Divinis Senteniis, had a more amateur and 'unpublished' translation by University of British Columbia professor, Courtney M. Booker, in 2015.

${ }^{31}$ Peter the Chanter's, Verbum Abbreviatum, is one of the widest ranging documents encompassing the faulty characteristics of the ordeals.

${ }^{32}$ Bartlett, Fire and Water.

${ }^{33}$ Ibid., 34-62. The fourth chapter in the book, "The End of the Ordeal and Social Change" covers the topic of a transition away from trial by ordeal in a social manner.

${ }^{34}$ Ibid., 70-103.

${ }^{35}$ Ibid., 127.

${ }^{36}$ Radding, "Superstition to Science", 945-969.
} 
Radding's main argument throughout the paper is, as science became slightly more advanced in the Late Middle Ages, the ordeals had lost all their credibility. Laypeople in the Middle Ages believed in God, saw the ordeals as God's justice, and did not look towards the increasing intellectual thought as the main downfall of the ordeal. The culture introduced by everyone in the Church played more of a factor in people's lives than Radding realizes. Clerics may have been skeptical whether or not the ordeals were working how they believed, but they were not superstitious about the power of God.

Another book looking at the history of the criminal trial is The Origins or Reasonable Doubt: Theological Roots of the Criminal Trial, by James Q. Whitman. ${ }^{37}$ Whitman looks at the Church more than either of the previous historians, but speaks more on the transition into trial by jury and other forms of proof. ${ }^{38}$ Whitman sees one of the main problems of the ordeals as there being no evidence at all, and subjecting the innocent to possibly harsh judgment by God. ${ }^{39}$ While this is true, he is approaching it from a modern point of view. Evidence in criminal trials was sparse in Europe. There is also speculation as to the belief that human testimony was more valid than the participation of God. ${ }^{40}$ Due to limited clerical writings on the ordeals, it is hard to speculate if the Church supported trial by jury or some other form of proof more than the ordeals. Following the Fourth Lateran Council, it is clear that the main objective in the outlawing of the ordeals had everything to do with moving to a better form of proof, on top of taking away the liabilities of officials in the Church hierarchy. ${ }^{41}$

Other key legal historians are Margaret $\mathrm{Kerr}^{42}$ and Elizabeth Papp Kamali. ${ }^{43} \mathrm{Kerr}^{\text {'s }}$ article looks into the science behind defeating the ordeals. Her argument revolves around the idea that the ordeals could be beaten, and most often were. The ordeals were in no way perfect, and Kerr shows this. Trial by fire was easily passed as the hand was covered for three days and had time to heal before it was displayed to a cleric or justice of the town. ${ }^{44}$ As long as there was no "disease discharge" at the end of the three days, the accused was cleared. ${ }^{45}$ Trials by cold water could easily be manipulated. Buoyancy was the main key to passing the ordeal. ${ }^{46}$ Kerr's writing answers the major question that Church officials were asking; could the ordeals be manipulated?

\footnotetext{
${ }^{37}$ James Q. Whitman, The Origins of Reasonable Doubt: Theological Roots of the Criminal Trial, (New Haven: Yale University Press, 2008).

${ }^{38}$ Ibid., 51-90. Whitman's third chapter deals with the ordeals and is called "The Decline of the Judicial Ordeals: From God as Witness to Man as Witness."

${ }^{39}$ Ibid., 85.

${ }^{40}$ Whitman, Origins, 85.

${ }^{41}$ Fourth Lateran Council, Canon 18.

${ }^{42}$ Kerr, "Cold Water and Hot Iron: Trial by Ordeal in England", 573-595.

${ }^{43}$ Elizabeth Papp Kamali, "Trial by Ordeal by Jury in Medieval England, or Saints and Sinners in Literature and Law", in Vengeance and Law in the Middle Ages: Essays in Honor of William Ian Miller, Brill Publishing (2018), 49-79.

${ }^{44}$ Kerr, "Cold Water", 588.

${ }^{45}$ Ibid.

${ }^{46}$ Ibid., 583.
} 
Papp Kamali's article tends to depict the miracles that took place behind the ordeals. She looks at a specific trial and shows how the accused was originally found guilty by a jury of knights after undergoing the ordeal by hot iron. The accused was later healed by the patron saint William of York. ${ }^{47}$ Less of an article on the ordeals, and more on the healing properties of Saints, Papp Kamali also provided insight into the later years, and final downfall of the ordeals. She points out that there is a jury of knights, which could be a sign of the transition period away from the trials by ordeal. ${ }^{48}$ Along with Kerr's article, Papp Kamali looks at issues relating to the ordeals that other historians seem to skim over.

It is quite odd that modern historians do not want to answer the question as to why theologians in the Church wanted nothing to do with the ordeals for many centuries. Even though there is sufficient primary writing to back up the significant views of the clerics, a single question remains. Is it possible to really know why the high-ranking officials wanted nothing to do with the ordeals apart from the writings of the Fourth Lateran Council? Yes. Very few historians attempt to link the papacy and church councils as the main, or even the sole, enemy of the medieval ordeal. Instead, they turn to a belief system that the trial by jury was more rational, and simply took over the trials by ordeal. In reality, at the time trial by jury was unheard of, and possibly even more irrational in the minds of lay Europeans.

\section{Hincmar of Rheims}

Through the time period of the ordeals not many people wrote in support of the trials. Much of the writing was devoted to the attacks on the ordeals. Everyone came to the general consensus, that if one was in support of the ordeals, it was not necessary to put it into writing. Nonetheless, one of the only theologians who supported the ordeals was Hincmar of Rheims (c. 806-882). Hincmar's most famous writing, De Divortio (The Divorce of King Lothar and Queen Theutberga), proves to still be the leading argument in favor of the use of the ordeals. ${ }^{49}$

In 855, King Lothar II inherited land north of the Frankish Alps from his father. This later became known as the Kingdom of Lotharingia. Throughout his time as King, Lothar II became close with his bishops. ${ }^{50}$ While he was becoming close with his bishops, so was his wife, Theutberga. Lothar II had been wanting to end his marriage with Theutberga for many years, and the chance finally came in 860 . Theutberga allegedly confessed to multiple bishops that she was unworthy to be Lothar II's wife. ${ }^{51}$ She had also confessed to at least one bishop that she had entered into an incestuous relationship with her brother, Hubert. ${ }^{52}$ Lothar began to restructure his

\footnotetext{
${ }^{47}$ Although William of York was later canonized as a Saint in 1227, he was not a Saint at the time of the miracle c. 1215.

${ }^{48}$ Especially in the Papal Interdict of 1208 against England, Pope Innocent III forced the Church officials to stay out of all business that did not pertain to the Church.

${ }^{49}$ Hincmar of Rheims, De Divortio.

${ }^{50}$ Ibid., 5.

${ }^{51}$ Ibid., 5.

${ }^{52}$ Hincmar of Rheims, De Divortio.
} 
argument for divorce around the idea that his Christian rule was being corrupted by the sins his wife was engaging in. ${ }^{53}$ Clerics and bishops in Lotharingia were hostile towards Lothar and his plans to divorce Theutberga. They would not grant Lothar II the divorce unless Theutberga nominated a champion to go through the ordeal in her honor. ${ }^{54}$ After going through the trial of boiling water, Theutberga's champion was deemed to have been unharmed. This proved Theutberga's innocence, and Lothar II was forced to restore her as Queen of Lotharingia. ${ }^{55}$ Because Lothar's followers believed his claims so thoroughly, this passing of the ordeal cast doubt on the validity of the ordeals as a tool for providing guilt or innocence. ${ }^{56}$ This is where Hincmar of Rheims came into play.

Hincmar had just recently been appointed to be the archbishop of Rheims. This provided him the opportunity to partake in the trial and write the most comprehensive argument towards the validity of the ordeals in the beginning centuries of the trials. Hincmar introduced many ideas not covered by other theologians in his time period. Much of Hincmar's argument had a Biblical basis and goes to show that the ordeals as a whole were an interesting part of both ecclesiastical and secular traditions. Along with the trial of bitter waters in the Bible, Hincmar argues that the Flood, and the punishment of Sodom showed the Biblical trials of fire and water. As a result, Hincmar argues that the ordeal of boiling water was particularly useful as it combined both elements into one ordeal. ${ }^{57}$ These Biblical ordeals became the main arguments for supporters of the trials. If God was picturing the ordeals in His scripture, then He must want humans to use them as well. Europeans were supposed to follow God's example, and one way they did this was modeling their trials after His.

The Flood pictured in the Bible set out the basis for the trial by cold water. God believed the world was corrupt, and full of violence. To rid the world of these evils He flooded the Earth for one hundred and fifty days. This was not before He told Noah and his family about the upcoming floods. Noah did all that God had commanded him to do and saved all the pure life forms that inhabited the Earth before the floods began. Noah's family, and everything aboard the Ark were saved, while all other life forms were killed by God's divine justice during the Flood. ${ }^{58}$ Hincmar of Rheims saw the Flood as the perfect example for the trials by cold water. ${ }^{59}$ From the earliest times of man, the ordeal had been used to administer God's judgment. Authority was handed down to Church theologians through God's word. The trial pictured by the Flood provided a prime example of God freeing the innocent and condemning the guilty ${ }^{60}$

Another example of the Biblical ordeals was the punishment of Sodom and Gomorrah. The flames of judgment that rained down upon Sodom and Gomorrah acted as the Biblical form

\footnotetext{
${ }^{53}$ Hincmar of Rheims, De Divortio.

${ }^{54}$ Ibid., 36.

${ }^{55}$ Ibid.

${ }^{56}$ Ibid.

${ }^{57}$ Ibid., Response 6: 163.

${ }^{58}$ Bible KJV, Genesis 6:9-9:17.

${ }^{59}$ Hincmar of Rheims, De Divortio, 150-155.

${ }^{60}$ Ibid.
} 
of trial by fire. Lot, the only man who had escaped the fires of Sodom, was the only one who passed God's judgment, and completed the ordeal. ${ }^{61}$ Hincmar pointed to this as the origins of the trial by fire. ${ }^{62}$ The fire burned up the wicked, and Lot, who was not a sinner, passed God's judgment and escaped the fires. These Biblical forms of these trials shaped arguments in support of the ordeals for many centuries. Priests within the Catholic Church adopted these doctrines that Hincmar supplied. They used them as evidence that they were in all legality when practicing the ordeals. In essence, divine law, which was pictured in the Bible, was transformed in human law, and practiced in the form of trials by ordeal.

Hincmar of Rheims used the stories of the Flood, and the fires of Sodom and Gomorrah to back up the use of the ordeals. Could they still be trusted? Was it clear that God wanted mortals to practice His forms of trial? Could these stories even be translated into trials? Hincmar is in the affirmative for all these questions. The Book of Numbers provides all the evidence needed to answer the question of whether the ordeals should be trusted. If a man suspected his wife of being unfaithful to him, he shall go to the priest. This priest will then have her stand before the Lord and do an oath with the bitter waters. If she has been unfaithful, her abdomen will swell, and she will miscarry the child she was carrying, but if she is innocent then nothing will happen. ${ }^{63}$

Although the Bible displays the use of ordeal-like trials, God did not specifically give humans confirmation to use the ordeals. This changes in the Book of Numbers, as Hincmar shows. ${ }^{64}$ The Lord gave priests the right to set humans before His divine judgment. This was the divine right that priests in the Church needed to continue the use of ordeals as a form of trial in the Middle Ages. Hincmar showed that the Bible alone passed down all the authority needed to practice the ordeals. They should be a practice that all theologians in Europe adopt, considering they were explicitly stated in the Bible. It was hard to deceive God, so therefore He will pass down His best judgment to those who went through the ordeals.

One major claim was that God had been tricked in the trial of Theutberga. ${ }^{65}$ This often became a common theme throughout the later history of the ordeals. Hincmar rejected the idea that God could be tricked. Lothar II convinced his people that Theutberga confessed her sins to a priest in Lotharingia. After going through the trial by hot water, her champion was deemed innocent because she had confessed her sins. ${ }^{66}$ Hincmar denied that this was the case. If Theutberga was going to perjure herself in the ordeal, the priest should have stepped in and stopped the trial from ever happening. ${ }^{67}$ Hincmar believed that breaking the seal of confession, on the part of the priest, is less serious than tempting or misleading God through the ordeals. ${ }^{68}$ If

\footnotetext{
${ }^{61}$ Bible KJV, Genesis 19.

${ }^{62}$ Hincmar of Rheims, De Divortio, 150-153.

${ }^{63}$ Bible KJV, Numbers 5: 11-22.

${ }^{64}$ Hincmar, De Divortio, Response 6: 145.

${ }^{65}$ Hincmar, De Divortio, 42-43.

${ }^{66}$ Ibid., 37.

${ }^{67}$ Ibid., 169-70.

${ }^{68}$ Hincmar, De Divortio, 169-70.
} 
it was the case that Theutberga and her champion were going to try and mislead God through the ordeals, then she would have been subjected to strict punishment in the afterlife. God sees everything and knew if the accused was trying to trick Him in their ordeal. ${ }^{69}$ Hincmar believed that if Theutberga had willingly confessed her sins to a priest, that priest should have stopped the ordeal, and broken the seal of confession, rather than let Theutberga perjure herself before God. ${ }^{70}$

Hincmar also rejected the idea that God could be tricked during the actual act of the ordeal. Lothar II also claimed that Theutberga had to have been thinking of another Hubert while the ordeal was going on. Because of this, Theutberga's brother, Hubert, was absolved of all legal responsibility. ${ }^{71} \mathrm{Had}$ this been the case, God would have realized it because He is omnipotent. It was incorrect to believe that God, who knows all things before they come to pass, could be misled by a human. ${ }^{72}$ Those who try to lie and mislead God will be damned for eternity and subjected to harsher judgments in the afterlife. ${ }^{73}$

In the trial by cold water, the one going through the ordeal was tied up for two reasons: (1) so he could not attempt to trick God in the final judgment, and (2) so he could be pulled out in time. ${ }^{74}$ Hincmar believed it was imperative to reduce the odds of trying to trick God, because it would ruin the true outcome of the ordeals. God already knew what the outcome of the ordeal was going to be. He would have known if there was any trickery going on during the process of the ordeal. If there was any possible chance of deception in the ordeal, then was it fair to stop using them as a form of judgment? Hincmar believed that those who were willing to try and deceive God deserved a "double vengeance of judgment." 75 If the accused was trying to evade His judgment through trickery, then they were undermining the integrity of the ordeals. They essentially deserved whatever God handed to them, both on Earth, and in the afterlife. Deceit in the ordeals was the Devil working against God's divine justice, and He would have easily recognized this. ${ }^{76}$

To further confirm the validity of the ordeals, Hincmar points to the sacrament of baptism as a form of the ordeal. The theologians in the medieval Church used baptism as a symbol of washing away the sins at the beginning of a new life. Hincmar believed that this was what was being done in the trial by cold water. ${ }^{77}$ The accused is bound and set into the water to be judged. He had all his sins washed away while also being judged by God. While this is not entirely the case, Hincmar showed comparisons between the two, and attempted to show that baptism was the earliest ordeal in life. The ordeals could have been thought of as a baptism for the innocent.

\footnotetext{
${ }^{69}$ Hincmar, De Divortio, 169-70.

${ }^{70}$ Ibid.

${ }^{71}$ Ibid., 37.

${ }^{72}$ Ibid., Response 8: 170.

${ }^{73}$ Ibid., Response 8: 172.

${ }^{74}$ Ibid., Response 6: 157-8.

${ }^{75}$ Ibid., Response 9: 176.

${ }^{76}$ Ibid., Response 9: 172.

${ }^{77}$ Ibid., 163.
} 
The Holy Spirit was a part of the water and washed away all sin. ${ }^{78}$ The case was similar for the guilty. In the end, though, he was judged for the crime he had committed. Most theologians in Hincmar's time argued that rebaptism should be avoided. The canons prescribed by the church councils forbid rebaptism. ${ }^{79}$ If trials by water were essentially a second baptism, they should not have been practiced. To Hincmar, as long as God's power is invoked in the act of the ordeals, then it was alright to go through a rebaptism. ${ }^{80}$ The Book of Colossians states that "whatever you do, whether in word or deed, do it all in the name of the Lord Jesus, giving thanks to God the Father through him." 81 This should acquit all those who go through a rebaptism, as long as it is in the name of God.

The writings of Hincmar of Rheims prove to be some of the only written confirmations of the use of the ordeals in the Middle Ages. Rightfully, Hincmar uses the Bible as the basis for all argument. If it comes from the word of God, it must be true. Although the Bible has instances where the ordeals could be derived, Hincmar needed to back his assertions with other passages from the Bible. He does this through the Book of Numbers, which gives priests the right to put the accused in front of God for a complete judgment. ${ }^{82}$ The accounts from the case of King Lothar II and Queen Theutberga provide a lot of questions for Hincmar to answer. They are questions that arise all throughout the Middle Ages pertaining to trials by ordeal. Can God be tricked? No, He has divine powers. Is it possible to beat the ordeals through non-divine ways? Yes, but God will know and punish those who try. Authority in the ordeals was handed down to the Church, which the Ark of the Flood symbolizes, in the Bible. In essence, Hincmar argues that God will always know the outcomes of the ordeals before they even take place. He is omnipotent and was supposed to use His divine judgment in any way that was asked for in the process of the ordeals.

\section{Agobard of Lyons}

The key critic against the ordeals in the Carolingian period was Agobard of Lyons (c. 779-840). Agobard's writings sharply contrasted with those of Hincmar of Rheims, even though they were writing in the same time period. It is interesting to see disagreement this early in the history of the ordeals, but by this point Agobard had the fullest and most complete record in arguing against the ordeals. His writing, De Divinis Sententiis, proved to be the sharpest attacks on ecclesiastical policies regarding the ordeals. ${ }^{83}$ Certainly, as the ordeals were continuously growing throughout his life, Agobard's ideas were not well received. Nonetheless, what he

\footnotetext{
${ }^{78}$ Hincmar, De Divortio, 151.

${ }^{79}$ Ibid., Response 6: 163.

${ }^{80}$ Ibid.

${ }^{81}$ Bible KJV, Colossians 3:17.

${ }^{82}$ Bible KJV, Numbers 5: 11-22.

${ }^{83}$ Agobard of Lyons, De Divinis Sententiis (Book on Divine Statements, Enumerated with very Brief Annotations, Against the Injurious Opinion of those Believing that the Truth of Divine Judgment is Revealed by Fire or Water or by Battle of Arms, c. 817-822), translated by Courtney M. Booker, University of British Colombia, 2015.
} 
argued soon became the center of Church theologians' arguments almost four centuries later. Although he mostly argued about the bilateral, trial by battle, Agobard also had key statements regarding the unilateral ordeals in his writing.

The main arguments of Agobard were either taken from the Bible, or assumptions made about God. One of his biggest arguments was that the priests conducting the ordeals were putting themselves in danger for their own judgment from God. The Bible says, "Thou Shalt not kill. And whosoever shall kill shall be in danger of the judgment. "84 The problem was that priests were being implicated in the killing of individuals when the accused was found guilty. ${ }^{85}$ Who was to say whether or not the members of the Church participating in the ordeals were actually implicating themselves in murder, and therefore leading to judgment in the afterlife? Agobard claims this to be a major problem with the ordeals.

Agobard argues that according to the will of God, instead of one killing a wicked man because of his sins, they should wait for the sinner to be punished in the afterlife. ${ }^{86}$ It is not up to the people to punish sinners. Agobard believes that the time for revenge is not in the present. Instead, the afterlife will be the perfect time for the guilty to be punished for their crimes. It is God who will punish one for their sins and crimes. One who does not "restrain the hand from murder, is also neither subject to the [Old Testament], nor is granted the freedom of the evangelical grace with the [New Testament]." ${ }^{87}$ The question was whether or not punishing a criminal by death was also a form of murder. Agobard thinks yes. It becomes hard for Agobard to justify killing in the ordeals when it is clear that God should be the one punishing for specific crimes.

To be a true patron of God, one must follow His example. ${ }^{88}$ In the ordeals, God did not punish the accused even if they were found guilty. Is this a sign that He has forgiven them of their sins? If God is not killing those in the ordeals, then why should His followers be punishing the guilty? The Bible again shows that those conducting the ordeals should forgive the accused of their crimes and let God have the final judgment. Agobard uses the Bible to argue, "For if you will forgive men their offences, your heavenly Father will forgive you also your offences. But if you will not forgive men, neither will your Father forgive you your offences." 89 The priests should not have been enforcing God's judgment without His explicit approval. It is a "great evil not to forgive the heart of a sinning brother." 90 Instead of forgiving the accused for his sins, the clerics put him through the ordeals to see if he was guilty or not. If he was to be found guilty, then he was punished harshly. Agobard argued that if you forgive the guilty of their crimes, then you would not be punished in the afterlife. On the other hand, if you punish those who were deemed guilty of God's judgment, then you were also subject to judgment in the afterlife.

\footnotetext{
${ }^{84}$ Bible KJV, Matt 5: 21-22.

${ }^{85}$ Agobard of Lyons, De Divinis, VI par. 7, 6.

${ }^{86}$ Agobard of Lyons, De Divinis, VI par. 61, 7.

${ }^{87}$ Ibid., VI par. 7, 6.

${ }^{88}$ Ibid., VI par. 9, 7.

${ }^{89}$ Matt. 6:14-15.

${ }^{90}$ Agobard of Lyons, De Divinis, VI par. 15, 7.
} 
It is known that "good men are killed by evil men, but never evil by good, unless in public wars. .." Those conducting the ordeals who participate in the killing of another individual were just as bad as those who commit murder against a good man. It is easier to forgive and let God pass down His judgments in the afterlife, than to implicate yourself in a murder and risk being judged for your actions. When one is prepared to take part in a mutual killing, there is no good will involved. God does not assist an individual in the killing of another. The clergy believed that they had the God given right to punish those who were found guilty in the ordeals. Agobard refuted all claims that it was alright to punish another through death. God does not really help either side in killing another. It is just believed that he helps one side because his judgment is invoked by the clergy. The question remains, though, was God's judgment really being called upon in the trials by ordeal? This was one of the Agobard's main arguments, and later became the basis for attacks from the high-ranking clerics. Both Agobard and Church theologians argued that one is unable to know if God ever acted in the ordeals.

The sole claim of the ordeals was that they were invoking the power of God. How was one supposed to know if this was ever happening? The ordeals became completely arbitrary, and their traditions could have easily been broken through normal means. It should be believed,

that nothing happens in the world, unless through the dispensation or permission of God, since even all the hair on the head of the faithful are counted, ${ }^{92}$ and one out of two or five sparrows does not fall to the ground without God, ${ }^{93}$ and as one of the saints says, Not even a leaf of a tree falls without God's consent. ${ }^{94}$

The members of the clergy conducting the ordeals assumed that they were being passed the power to administer God's judgment. God never really gave them His consent to punish individuals for their crimes though. In fact, Agobard goes against Hincmar and states that the Bible forbade these types of trials. Scripture says that one must not kill, yet the members of the clergy killing the guilty. Everything that happens on the Earth happens because of God's will. Those who commit crimes are not punished by God for a purpose. Therefore, God's judgment should not be invoked unless he explicitly says it must be practiced. If the omnipotent God wanted to punish sinners while they were on Earth, He would have done it Himself. Instead, if $\mathrm{He}$ is acting in the ordeals, it should have been apparent that He is a kind and forgiving God. He was waiting until the afterlife to punish the accused for their crimes. He was not doing it while they are still on Earth, and neither should the clergy. The wisdom of God should be sought with absolutely no doubt in its accuracy. ${ }^{95}$ It was a worry in the Middle Ages, and especially following the writings of Agobard, that God's wisdom was not taking action in the ordeals. This

\footnotetext{
${ }^{91}$ Agobard of Lyons, De Divinis, V par. 2, 4.

${ }^{92}$ Matt. 10: 30.

${ }^{93}$ Matt. 10: 29.

${ }^{94}$ Agobard of Lyons, De Divinis, V par. 1, 4.

${ }^{95}$ Agobard of Lyons, De Divinis, III par. 2, 3.
} 
proves to be a big issue surrounding the outcomes of the ordeals. Could one count on the wisdom of God to protect himself? Or were they going through an arbitrary trial?

The Latin name for the trial by ordeal is iudicium Dei, or literally, "judgment of God." This insinuates that God was taking part in the ordeals. There was to be no denying this claim. How can it "be proven that it [was] a judgment of God, which God never prescribed, never wanted, and never show[ed] as included in the examples of the Saints and of all the faithful?"96 Human law set out the ideas and stipulations for the ordeals, not divine law. Although there were ordeals in the Bible, as Hincmar showed, God never explicitly allowed the use of ordeals. Agobard would argue that God never gave written consent in the Bible to practice the ordeals. Even if the Bible acted as a way to follow His wisdom, the ordeals in it were practiced almost a thousand years earlier. How could it be known if this form of divine law was still accepted by God? While Hincmar argued that God directly prescribed the ordeals, Agobard argued the opposite. God never wanted this form of judgment, and He never called for members of the clergy to practice it in His name. This, again, brings up the question of whether God was really taking part in the act of the ordeals. The trials are based around God's participation. If He never wanted them, then did He ever pass down His judgment upon the accused?

Agobard went further and argued that "... the judgments of God are secret and impenetrable. It follows that it is foolish and arrogant presumption of those who believe they can make manifest unequivocally, through wars and massacres, the impenetrable judgments of God." ${ }^{, 97}$ Even if God wanted to partake in the ordeals, He would not reveal His judgments to humans. The wisdom of God acts in secret, and only affected those in the afterlife. There was no way to know what He wanted or thought in regard to the ordeals because he was not subject to reveal His judgments. God wanted to wait until death to punish those who sinned. In another of his writings, Agobard claims that "the faithful should not believe that almighty God wishe[d] to reveal men's secrets in the present life through hot water or iron."98 The trials by ordeal should not be used to reveal the judgments of God, because this was not His main priority. Instead the judgments were to be revealed in secret, and in the afterlife. Mortals had no business trying to pry answers and wisdom out of Him. They had no proof that God was assisting in the outcomes of the ordeals.

The arguments of Agobard of Lyons prove to be some of the leading ideas in disputing the ordeals in the Carolingian period. His ideas became the basis of argument for the highranking theologians in the Church leading up to the Fourth Lateran Council. The papacy and church councils became increasingly worried that their clerics were heading into an afterlife where they will be punished for their help in the ordeals. God's judgment should not have been revealed through simple human trials. The time for revenge was not up to members of the Church to decide. These arguments, while the earliest in the history of the ordeals, prove to be

\footnotetext{
${ }^{96}$ Agobard of Lyons, De Divinis, II, 2.

${ }^{97}$ Ibid., VI par. 44, 7.

${ }^{98}$ Agobard of Lyons, Liber Adversus Legem Gundobadi, p. 25. Depicted in Robert Bartlett, Trial by Fire and Water: The Medieval Judicial Ordeal, 72.
} 
some of the sharpest and most complete. Leading up to the Fourth Lateran Council, Agobard's arguments were continuously cited by critics of the ordeals. Four centuries after the writings of Agobard of Lyons, the main arguments against the ordeals essentially stayed the same. They simply increased in volume and became the main downfall of the ordeals.

During the Carolingian period the ordeals continued to grow and solidify their place in European legal tradition. While it was still early in their existence, this ninth-century material from Agobard of Lyons proved that it was possible to be hostile towards the ordeals. It became apparent that the ordeals were subject to theological disputes. At this point in time the critics were the minority. While few voiced their support of the ordeals, even less rejected their use. The laity saw ordeals as a form of instruction, priests received gifts and fame for the completion of an ordeal, and very few Popes wrote out against their use before $1050 .{ }^{99}$ It is clear that Agobard led the way for theological attacks on the ordeals. He opened up new ideas that Church officials had never thought of before the turn of the millennium. Despite the impact Agobard had on twelfth and thirteenth century ecclesiastical philosophy regarding the ordeals, he is rarely cited.

\section{Attacks on the Ordeals from within the Church}

The attacks against the ordeals were compiled through the years by the high-ranking officials in the Church itself. Although theologians like Hincmar believed the ordeals had Biblical origins, this became one of the main disagreements laid out by medieval clerics. Instead, theologians working with the Church argued that "ordeals violated Biblical prohibitions against tempting God, particularly since many issues decided by ordeals could also be resolved by other, nonmiraculous means." 100 Yes there are ordeals in the Bible, but God initiated them, and they occurred almost a thousand years earlier. Who was to say this was the way God still wanted to decide His justice? The views on the ordeals changed when people on Earth began to practice them themselves. Is this what God wanted? This was a question that theologians began to ask themselves. It was one thing for people to follow the word of God in their everyday life, but when the legal system started to imitate God, and force His judgments in human matters, the leaders of the Church began to grow weary of European legal tradition. ${ }^{101}$

In the Middle Ages, most Europeans believed that nature responded to the will of God, "these beliefs about the world invited reliance on the ordeals. . if God's justice did not determine who sank in water or escaped maiming by the hot iron, how else would such results be explained?"102 Indeed, without modern science, there were only a few other ways to explain what was happening in the ordeals. The ordeals revolved around the existence of God's judgment here on earth. Because the ordeals were working on supernatural forces, it was good instruction for

\footnotetext{
${ }^{99}$ Bartlett, Fire and Water, 75.

${ }^{100}$ Radding, "Superstition”, 945.

101 Radding, "Superstition", 945.

102 Radding, "Superstition", 965.
} 
laypeople watching them. For the Church officials it was a different story. How could the ordeals be explained if God was not acting in them? For the laity of Europe in the Middle Ages, the ordeals were directly tied to God and His judgment.

The goal of the ordeals was to reveal a specific fact of whether or not the accused was guilty or innocent. The intellectuals within the Church worried that this was not working in the way they envisioned. The function of the ordeal was "diluted by the belief that God might be using the ordeal to show mercy, justify the good at heart, or punish the sinner whether he happened to be guilty in the case at issue." ${ }^{103}$ While God was supposed to be merciful, still too many defendants were coming out of the ordeals innocent. To Church clerics, these uses for the ordeal went against what they intended them to depict. God was supposed to reveal the guilty and allow for them to be punished. If the accused was being punished, though, another question arose. Was the punishment for the crime they were accused, or for another set of sins? Although the idea of the ordeals was practical in a religious sense, they bring up many questions as to if God's judgments were being used in the manner that people intended them to. The secular courts intended to control God's judgments and be able to use them for their own purposes. The laity in Europe rarely noticed any of these discrepancies. It was the Church intellectuals who began to question the legitimacy of ecclesiastical involvement in the ordeals. Could the ordeal still be considered a valid use of God's justice? Ultimately, another question arises. Why use the ordeal when God can just punish the accused in the afterlife? Medieval priests preached on sin consistently through the Middle Ages, and the wrath of God scared people. ${ }^{104}$ Those people who sinned would be harshly punished in Hell for eternity, not in the middle of a European town. Why is it priests assumed this was how the ordeals would work?

A common theological attack on the ordeals was that the ordeals violated Biblical prohibitions against tempting the power and judgment of God. ${ }^{105}$ God's power could easily be called upon, but there was no way to know if He was playing a role, or if He was absent. Although God could intervene in the sermons through the Eucharist, it was still worried that He would not do the same in the trials. Instead this is not quite what happens. The theologians in the Church began to notice that the ordeals were just a coincidence in procedure early on, even though they had no other way to describe them other than by calling it God's judgment. Every stage of the ordeals was to be done with the utmost precision. After going through these long processes for low conviction rates, theologians began to realize the ordeals had lost their social utility and had run their course. ${ }^{106}$ This lengthy process allowed for the accused to go through their thoughts and try to make a last-minute compromise with the priest, or with God Himself. ${ }^{107}$

\footnotetext{
103 Bartlett, Fire and Water, 79.

${ }^{104}$ Caesarius of Heisterbach gives different sermon stories from the Middle Ages in The Dialogue of Miracles. They picture all different topics, but many of them deal with sins by Church members, and how they are punished by the wrath of God. A few of the sermon stories deal with the ideas of trials by ordeal and show the traditional views of God's justice being put to work.

105 Radding, "Superstition”, 945.

${ }^{106}$ Ibid., 956.

107 Ibid.
} 
While this did not occur often, it is still a point that can be expanded upon. A compromise, just like a plea bargain in modern standards, allow for the accused to escape the wrath of God, at least until the afterlife. The accused could instead confess their sins and lead a life of penance. If the accused chose to go through with the ordeal, the entire process must have been taken seriously by the priest. The scripts had to be followed as closely as possible, or risk losing the judgment of God in the process. ${ }^{108}$ Who was to say that the clerics were practicing the ordeals right and fully invoking the power of God? One of the biggest worries of the Church clerics was whether their priests were performing the ordeals correctly. Were they putting laymen through these harsh ordeals, and God not acting as they wished? Priests believed that God was playing a role in the ordeals, but high-ranking theologians began to grow more skeptical. If they believed God was not having an impact, though, they would not have publicly stated it. This would have made the laity wonder if God was an essential part of their lives at all, or if their lives were just one long, enduring ordeal.

The Church never introduced the ordeals into their ecclesiastical trials. There is dispute among early theologians, especially Hincmar of Rheims, whether baptism was a form of a trial by ordeal. Even though they were secular trials, the ordeals heavily relied on the involvement of priests. The papacy never gave explicit consent to their clergy members to assist in the ordeals. ${ }^{109}$ Instead, it was “' an invention of men' a 'proof which God never ordered and never wished and which, as can be demonstrated, was not introduced through the example of any of the saints or any of the faithful." 110 Mankind believed that God was handing the trials down to them through Biblical events. High-ranking Church officials thought the opposite of this. The existence of material against the ordeals as early as the ninth century showed that objections were raised against the ordeals very early in its history. ${ }^{111}$ Critics towards the ordeals were the minority in the early years. Most laymen, clerics, and popes, up until 1050, did not publicly express outrage against the use of the ordeals. While this was the case, in reality people in the Middle Ages did not have to speak their ideas publicly. It was well known who supported, and who opposed the ordeals. Laymen supported the ordeals because they were coming into close contact with the omnipotent God. ${ }^{112}$ Priests supported the ordeals because it brought them into a closer connection with God. Priests now had the power to determine God's judgment. ${ }^{113}$ The Popes and high-ranking theologians very often wrote out against the use of ordeals. No Pope or Church council, though, ever attempted to end European use of the ordeals. ${ }^{114}$ The ordeals were unpopular with the majority of the high-ranked individuals of the Church all throughout their

\footnotetext{
108 Radding, "Superstition", 956.

${ }^{109}$ Hincmar of Rheims gives this view of baptism in his writing De Divortio. He believes it is the earliest ordeal that can happen in life as a trial by water, and that through it, God is cleansing the soul and ridding it of the original sins that mankind is believed to have made.

${ }^{110}$ Bartlett, Fire and Water, 73.

111 Ibid., 75.

112 Ibid., 42-43.

113 Ibid., 41.

${ }^{114}$ Ibid., 74-76.
} 
lifespan. Critics of the ordeals were quiet in the early years, but as the ordeals lost their social utility, they became more outspoken. The attacks began from the top and started to trickle down the hierarchy as the years passed. Critics of the ordeals soon became the majority of the Church's clergy.

It was not until 1215 that any form of ecclesiastical council began to regulate the use of the ordeals. While there was major animosity towards the use of the ordeals in Europe, there was little inclination that all the attacks waged against the ordeals would culminate in such a swift downfall. The attacks coming out of the Church became the basis of ecclesiastical views on the ordeals for over three centuries. Despite this, the canons compiled by the ecclesiastical lawyers at the Fourth Lateran Council were still significant. Very few Popes wrote in opposition to the ordeals. The Popes Leo IV (r. 847-855), Stephen V (r. 885-891), Sylvester II (r. 999-1003), Alexander II (r. 1061-1073), and Alexander III (r. 1159-1181) all publicly wrote out against the use of the ordeals with their high power. Despite this, they were all disregarded. Many highranking theologians expressed their mistrust, yet over three centuries of writing still was not enough to overshadow the approval that medieval priests had for the ordeals. What was it that made Pope Innocent III and the members of the Fourth Lateran Council finally withdraw ecclesiastical support from the ordeals in 1215 ?

\section{Fourth Lateran Council, 1215}

Many historians claim that the years of the Fourth Lateran Council were an intellectual preparation leading to a more modern criminal procedure. Robert Bartlett finds that abandoning the ordeals was an intellectual commitment, giving more control to the Church hierarchy, and explicitly placing the power of the Church into Pope Innocent III's hands. ${ }^{115}$ John Baldwin claims the end of the ordeals was the beginning of a new era in criminal trial. ${ }^{116}$ These ideas prove to be true for secular trials, but the ecclesiastical tradition never had a form of trial similar to the ordeals. The ordeals were simply a secular trial, that brought in the aid of local priests. Did the papacy and high-ranking theologians ever really condone ecclesiastical involvement? Early on, yes, but as the trials became more pronounced in Europe the outrage became more apparent. What must first be understood about the Fourth Lateran Council is that their goal was to outlaw ecclesiastical involvement in the ordeals, and mandate new provisions for the Church courts. While the Council played a large impact on secular use of the ordeals, their jurisdiction was only for the Church courts. While the Fourth Lateran Council could not completely outlaw European use of the ordeals, the restriction of priest involvement paved the way for their eventual downfall.

Pope Innocent III is widely known as having been one of the most powerful popes coming out of the Middle Ages. He brought major reform to the Church, and attempted to

\footnotetext{
${ }^{115}$ Bartlett, Fire and Water, 100.

${ }^{116}$ John W. Baldwin, “The Intellectual Preparation for the Canon of 1215 Against Ordeals," Speculum, 36, no. 4 (1961): 613-636.
} 
consolidate his, as well as clerical power. A few popes before that time wrote against the use of the ordeals, but no one took as big of a step on outlawing them as did Pope Innocent III. Pope Stephen V (r. 886-9) proved to be the earliest critic of the ordeals of fire and water in the papacy. ${ }^{117}$ In his essay, Consuluisti, Stephen V called the ordeals a "superstitious invention," and condemned the practicing of the trials because they were not sanctioned by the holy fathers. ${ }^{118}$ Despite this, Pope Stephen V's ideas were not taken seriously, and the ordeals only got stronger during his period of rule. During his rule (1198-1216), Pope Innocent III showed no signs of animosity towards the ordeals. In his written letters, Innocent III never once mentioned the ordeals. Why did this change in 1215 with the Fourth Lateran Council? The Council was a way for high-ranking members in the Church to consolidate ecclesiastical power in many areas. There was an increasing pressure from theologians to reform ecclesiastical policies relating to the ordeals. The members of the council saw this as a perfect opportunity to condemn the practice.

The overwhelming majority of historians who cover the ordeals only look at Canon 18, Sententiam sanguinis, ("Judgments of Blood"). This is a grave understatement of the impact that the Fourth Lateran Council had on reforming ecclesiastical participation in the secular ordeals. Theologians at the Fourth Lateran Council condemned the participation of all Church officials in the ordeals. While the secular courts could still practice this form of trial in Europe, they would no longer have the help of the Church priests. This would prove to be a problem when attempting to invoke God's participation.

Theologians also reformed the future use of ecclesiastical trials with the hopes these canons would forever end priestly involvement in secular trials. There are a total of three canons which apply to the ecclesiastical downfall of the ordeals coming out of the Fourth Lateran Council. Canon 8, Inquisitio ("On Inquisition"), and Canon 38, Quoniam contra falsam ("Written Records of Trials to be Kept"), along with Canon 18 provide all everything that pertains to the future of ecclesiastical trials. ${ }^{119}$ While Canons 8 and 38 do not explicitly state anything about the ordeals, they still provide key testimony to the animosity held towards the trials.

In order to understand why the council members set out multiple provisions in the Fourth Lateran Council, we much understand what the clerics stood to gain. Criminal procedures were largely the responsibility of the countries, not the Church itself. Although it seems like the Church and clergy had special control over the ordeals, they essentially never had any sort of ecclesiastical control. Pope Innocent III looked to rearrange the hierarchical standing over Church criminal procedure and enhance the efficiency of the new trials themselves. ${ }^{120}$ As the

\footnotetext{
117 Bartlett, Fire and Water, 74.

118 Ibid., 74.

${ }^{119}$ Fourth Lateran Council, c. 8, c. 18 , c. 38.

${ }^{120}$ Richard M. Fraher, "IV Lateran's Revolution in Criminal Procedure; The Birth of Inquisitio, the End of the Ordeals, and Innocent III's Vision of Ecclesiastical Politi”, in Studia in Honorem Eminentissimi Cardinalis Alphonsi M. Stickler, Roma: LAS, (1992), 99.
} 
priests had become corrupted by the power they gained in their practice of the ordeals, the high ranked clergy members looked to bring order back to the medieval Church.

In order to impose introduce the use of new ecclesiastical trials, Pope Innocent III and the rest of the Church leaders laid out a series of ideas on what a correct Church procedure should look like. While these ideas did not explicitly pertain to the downfall of the ordeals, they are important to understanding why theologians had lost trust in the use of the secular ordeal. First, there must be a quality of fairness to trials. They must not be arbitrary but also cannot go entirely in the favor of the accused. ${ }^{121}$ Legitimacy was a key factor in the downfall of the ordeals. Who was to say that God was actually being an impartial judge? Although the ordeals are fair in favor of the defendant standing trial, the legitimacy factor had a big effect on the leaders of the Church. Second, trials in Europe were supposed to be reasonably efficient at producing convictions. ${ }^{122}$ In this aspect, the ordeals were not ideal. Considering two-thirds of the accused who went through the ordeals came out innocent, the ordeals had an overall problem with producing convictions. Now, if God were making the decisions, then ideally this grouping for trials would be arbitrary. When combined with the first criteria, if the ordeals were not legitimate, then they would not have been considered to have produced efficient convictions during the trials. The last criteria concerning medieval trials would have been that the highranking clerics had to have a sense of control over the trials. ${ }^{123}$ There had to be a direction that the trials were going. The Council had to be able to enforce a systematic, and permanent institutional reform. During the latter years of the ordeals the Church had lost control over their priests' involvement. Members of the clergy were practicing the ordeals all over Europe, and there were not many ways that the Church could have a sense of control over their clerics.

As far as the ordeals went, they did not follow any of these criteria. It could be argued that in a sense they had a legitimacy to them. Ordeals were very popular among lay people. Many plays were written that contained a form of the ordeal, and people often congregated to use the ordeals as a learning experience. ${ }^{124}$ If this was the case, then there must have been people all over Europe who believed that the ordeals had a sense of fairness and originality. The second and third criteria, as shown, did not apply to the ordeals. The rates of conviction are arbitrary if there is no legitimacy to the trials, and the ordeals could not be controlled by the Church as they were never ecclesiastical. The ordeals were key for people looking to promote the omnipotence of God, but by the thirteenth century they had lost all their ecclesiastical function. ${ }^{125}$ Lawyers and theologians had finally lost all confidence in the results of the ordeals. Because of this, the Fourth Lateran Council looked to consolidate the power of the Church clerics, and attempt to force the ordeals out of Europe.

\footnotetext{
${ }^{121}$ Fraher, "IV Lateran," 101.

122 Ibid.

${ }^{123}$ Ibid.

${ }^{124}$ See fns. 152 and 153.

${ }^{125}$ Bartlett, Fire and Water, 89.
} 
The eighteenth canon coming out of the Fourth Lateran Council is one of the most cited ideas leading to the complete destruction of the ordeals. Appropriately called the "Judgments of Blood," modern historians often over explain what this canon meant for the use of ordeals. Highranking officials in the Church were worried that their priests would be subjected to God's judgment in the afterlife. As the ordeals gained more power, priests became more implicated in their use and were essentially sentencing the guilty to death. Theologians did not want to be associated with killing possibly innocent people. ${ }^{126}$ Canon 18 applies to more than just the ordeals. Members of the Fourth Lateran Council did not want the blood of anybody on the hands of their priests. This would shape the form of a new age of ecclesiastical trial. A form of trial in which priests were not tasked with finding out guilt or innocence and determining a punishment. This is the only canon that explicitly states reforms on the ordeals, and that is why it is the only canon cited among historians. The main objective of a priest in the ordeals was to bless the items being touched by the accused, so as to invoke God's judgement. The Fourth Lateran Council noticed this and stated, “. . . nor may anyone confer a rite of blessing or consecration on a purgation of ordeal. ." 127 This took all responsibility away from the clerics. Canon 18 is easy to interpret as a decree against the ordeals because it explicitly states that the ordeals can no longer be practiced by Church officials. Priests were told they could no longer participate in the secular ordeals, and officials in the Church looked to enforce this through new ecclesiastical trials.

Canon 8 ("Of Inquest") of the Fourth Lateran Council was the first attempt for the canon lawyers to establish a new form of Church trial. If applied in conjunction with canon 18, it would seem that the eighteenth canon repealed priest involvement in the ordeals, and the eighth canon established what the priests should actually be focusing their attention on. ${ }^{128}$ Pope Innocent III believed that the inquisitorial process had more scriptural foundation than the ordeals. ${ }^{129}$ The more scriptural foundation there was, the more chance that God would support the outcomes of the trials. The Fourth Lateran Council looked to have cases proceed in three areas: by accusation, denunciation, and inquest.

Canon 8 looked to go forward with the idea that if one were to accuse another of a crime, there must be a thorough investigation, or inquest, into the facts, or lack thereof concerning the case. ${ }^{130}$ Innocent III and the Fourth Lateran Council looked to perform trials where there was evidence present. This did away with the trials where there was an accusation with little belief in the claim, but this was the goal of Innocent III and the members of the Council. They were looking to increase the legitimacy of ecclesiastical trials, make them more efficient at producing convictions, and take away the responsibility of the clerics performing the ordeals. As far as enforcing this canon went, clerics were threatened with removal from office if they were caught practicing any other form of medieval trial, not consistent with church policy.

\footnotetext{
${ }^{126}$ Fourth Lateran Council, c. 8

127 Ibid., c. 18

${ }^{128}$ Ibid., c. 8

${ }^{129}$ Fraher, "IV Lateran," 106.

${ }^{130}$ Ibid., 99-100.
} 
The last canon concerning reform for trials in the Middle Ages was canon 38 ("Written Records of Trials to be Kept") of the Fourth Lateran Council. While it may sound selfexplanatory from the title, this idea put forth by the Council is more complex. The canon discusses many topics concerning the future of ecclesiastical trials. The Fourth Lateran Council noted that a simple denial in a criminal trial was not enough evidence to make a decision. ${ }^{131}$ Even with a lack of evidence, there must be an ecclesiastical inquest. Direct proof in medieval trials was hard to come by, but just because there was no proof, and a denial by the accused, it did not mean the trial was over.

Furthermore, the Catholic Church looked to limit the corrupt nature of priests in the Middle Ages. Theologians noticed this and decided that "falsehood, prejudice[d] truth, or wickedness [should not] prevail over justice."132 They did this through forcing the priests and justices to employ a scribe at every trial. This provided a witness to the events and provide a written record for Church officials to review if there was a claim that the trial was unfair. Scribes were tasked with faithfully writing out all judicial acts that went forth in the trial. ${ }^{133}$ This provided evidence to all parties of the correct outcomes of cases and provided a written account for all ecclesiastical trials that occurred in Europe. This canon provided faith that justice for the innocent would not be harmed by wicked or corrupt judges across Europe. As in canon 8, the Catholic Church looked to enforce this canon through threat of removal and punishment of the judge presiding over a case. How does this canon pertain to priestly involvement in the ordeals? If written records of trials were to be kept, Church officials could closely monitor how priests and Church justices were conducting ecclesiastical trials. If they were not applying new ecclesiastical policies, they would be subject to punishment.

Theologians were looking to further legitimize ecclesiastical trials in the years following the Fourth Lateran Council. Pope Innocent III and the Church realized they had lost control over their priests in Europe, and the ecclesiastical mistrust of the ordeals had been going on for centuries. This culminated in the downfall of the ordeals in 1215. While the Fourth Lateran Council could not explicitly outlaw the use of secular ordeals in Europe, they acted as the trend setter. Theologians wanted ecclesiastical trials to have prestige over the secular trials. Because of this they withdrew all support for the use of the ordeals. While the secular ordeals could have sufficed for a few years following 1215, the inability to effectively call for God's judgment impaired the use of the trials. It the laity had seen someone who was not a cleric invoking God's help in the ordeals, would they believe the trials were legitimate? The ordeals never had an ecclesiastical basis, and further lost support when the Fourth Lateran Council looked to reform and enforce a new era of Church trial. Church courts had a limited jurisdiction on European crime, yet they wished to show all of Europe how they should be established new trials and leaving the medieval ordeals in the past. As Robert Bartlett argues, the ordeals had lost all their social function following the convening of the Fourth Lateran Council in 1215. While this is

\footnotetext{
${ }^{131}$ Fraher, "IV Lateran," 108-109.

132 Fourth Lateran Council, c. 38.

${ }^{133}$ Fraher, "IV Lateran," 109.
} 
true, the ordeals had lost their ecclesiastical function centuries earlier. For many years highranking theologians fought with the use of the ordeals yet could not do much as they were secular in nature. The only ecclesiastical basis was the invoking of God's judgment through priestly incantations. As the canon lawyers of the Fourth Lateran Council outlawed participation of Church officials in the ordeals, their final downfall was complete.

\section{Conclusion}

The overarching question of this project was to examine why the ordeals lasted so long if there was such a large theological dispute within the Church. Only one key theologian gave such broad support to the use of the ordeals, and that was Hincmar of Rheims. Hincmar laid out the basis of the Biblical arguments surrounding the ordeals and pushed for the Church to fully accept them. The rest of the learned community within the Church blatantly disagreed with the use, as well as the execution of the ordeals. Agobard of Lyons was one of the earliest refuters of the ordeals for many reasons. His main arguments against the trials were the ones that Church theologians adopted leading up until 1215, and the complete downfall of the ordeals. How can the ordeals be a judgment of God, when He never wanted, and never agreed to help in the ordeals? Hincmar attempted to prove that God called for use of the ordeals through His word. The Flood, and fires of Sodom and Gomorrah provided for the basis of the medieval ordeals, and the Book of Numbers provided the key Biblical support. Theologians opposing the use of the ordeals added the worry that clerics would be punished in the afterlife for participating in the death of a loser in the ordeals.

The ordeals supplied a means of awing the laity through divine justice, the priest became a special instrument of the trials, and the decisions of life and death fell into the hands of everyday clerics. ${ }^{134}$ During the period of the ordeals, priests found power, profit, and prestige. Naturally, they were unwilling to abandon the use of the ordeals for a completely different ecclesiastical system. They were especially weary following the canons set out in the Fourth Lateran Council of 1215. Following the complete outlaw of the ordeals, clerics had a hard time completely abandoning their use. ${ }^{135}$ The only immediate abolition of the ordeals came in England, where the monarch replaced the ordeals with the now popular trial by jury. ${ }^{136}$ This is a rough claim though considering England had a head start following the Papal Interdict of 1208, in which Pope Innocent III prohibited clergy members from taking part in government trials. Considering the clergy were an integral part of the ordeals, this Interdict led to the complete downfall of the ordeals even before the Fourth Lateran Council met. Other areas on the

\footnotetext{
${ }^{134}$ Bartlett, Fire and Water, 41.

${ }^{135}$ Whitman, Origins, 53.

${ }^{136}$ Ibid., 53.
} 
continent, including those in the Germanic world practiced the ordeals for many years following their outlaw. ${ }^{137}$

On top of being popular with lower clerics in European society, the ordeals provided a sense of instruction for the laity. Although God was not striking anybody down at the conclusion, His presence was felt in every ordeal. High ranking members in the Church wondered if God was actually making judgments in the ordeals, but if the laypeople in European society did not believe God was playing a factor, they faced a different form of judgment amongst their peers. ${ }^{138}$ Many medieval writers also used the ordeal to their advantage. Gottfried von Strassburg's popular play, Tristan, utilized the ordeal in the same way that it is pictured in the trials of King Lothar II and Queen Theutberga. ${ }^{139}$ In England, a poet wrote Athelston, which also pictured the ordeal in major fashion. ${ }^{140}$ The ordeals were not just a trial that laypeople were forced to watch on occasion. Instead, the ordeals surrounded the everyday lives of Europeans in the Middle Ages. Although ordeals were not the main form of criminal trial used, lower clergy members were enveloped in their use.

The loss of control over the ordeals scared Church theologians the most in the Middle Ages. Through the process of the Fourth Lateran Council, canon lawyers laid out three basic requirements for the future of the medieval trials. Future ecclesiastical trials had to be legitimate, produce convictions efficiently, and be susceptible to control from the higher powers in the Church. Was it possible that the Council could have reformed trials by ordeal? Highly unlikely. The goal of the Fourth Lateran Council was to show its mistrust in the ordeals, finally outlaw them, and implement new policies for Catholic Europe to implement. These new policies were laid out in canons 8, 18, and 38 coming out of the provisions of the Fourth Lateran Council. The canon lawyers looked to implement a new system of inquisition, forbid clerics from participating in trials that resulted in death, and forced judges to hire scribes to document the outcomes of trials. This gave the theologians complete control over the future of all ecclesiastical trials in Europe. The biggest requirement was the factor of control for Pope Innocent III and other canon lawyers in 1215. Without a sense of control, could the Church utilize its full utility and power? Probably not, and Pope Innocent III recognized this.

Modern historians have given an incomplete review of Church policies regarding the ordeals leading up to 1215. While they lay out all the arguments against the use of the ordeals, they refuse to give a complete account on the downfall of the ordeals. Canon 18 of the Fourth Lateran Council, often referred to as the "Judgments of Blood", is one of the most cited ideas coming out of the Fourth Lateran Council. While clerics playing a role in the death of the laity was a big deal to Church officials, overall it was the loss of control that provided the basis for

\footnotetext{
${ }^{137}$ Wilfried Hartmann and Kenneth Pennington, The History of Medieval Canon Law in the Classical Period, 1140 1234, (The Catholic University of America Press, 2008), 347.

${ }^{138}$ Hincmar, De Divortio, Response 9: 176.

${ }^{139}$ Gottfried von Strassburg, Tristan (12 ${ }^{\text {th }}$ c.), translated by A.T. Hatto, Baltimore: Penguin Books, (1960), $245-248$.

${ }^{140}$ Athelston $\left(14^{\text {th }}\right.$ c.), edited by Ronald B. Herzman, Graham Duke and Eve Salisbury in Four Romances of England. Kalamazoo: Medieval Institute Publications, (1999).
} 
outlawing ecclesiastical participation in the ordeals. Is the lack of academic work on the downfall of the ordeals incomplete? Yes. Is it because Church policies regarding the ordeals are tough to interpret? No. Everything needed to understand the ordeals, and the trials replacing them, are in the writings of Agobard of Lyons and Hincmar of Rheims. These arguments provided both the leading supports and arguments against trials by ordeal in the Middle Ages.

Agobard of Lyons writings helped lay the basis for the attacks from within the Church and left the writings of Hincmar of Rheims in the ninth century. Arguments were compiled in the years leading up to 1215, and finally culminated in the Fourth Lateran Council. Pope Innocent III and canon lawyers took away all clerical support in the ordeals and attempted to implement new forms of ecclesiastical trials. The downfall of the ordeals was not an abrupt decision by the canon lawyers in the Church hierarchy. Instead, it was a fiery culmination of many centuries of disgust, and the need for the theologians to have a sense of control over Church trials in medieval Europe. 


\section{Bibliography}

Assize of Clarendon in 1166.

Assize of Northampton in 1176.

Baldwin, John W. "The Intellectual Preparation for the Canon of 1215 Against Ordeals." Speculum36, no. 4 (1961): 613-36.

Bartlett, Robert. England Under the Norman and Angevin Kings: 1075-1225. Oxford: Oxford University Press, 2002.

Bartlett, Robert. Trial by Fire and Water: The Medieval Judicial Ordeal. Brattleboro, VT: Echo Point Books \& Media, 2014.

Fraher, Richard M. 'IV Lateran's Revolution in Criminal Procedure; The Birth of Inquisitio, the End of the Ordeals, and Innocent III's Vision of Ecclesiastical Politi." Studia in Honorem Eminentissimi Cardinalis Alphonsi M. Stickler, 1992, 97-111.

Fourth Lateran Council in 1215.

Glanvill, Renulf De. The Treatise on the Laws and Customs of the Realm of England Commonly Called Glanvill. Edited by G. D. G. Hall. New York: Clarendon Pr., 2002.

Hartmann, Wilfried, and Kenneth Pennington. The History of Medieval Canon Law in the Classical Period, 1140-1234: from Gratian to the Decretals of Pope Gregory 9. Washington: Catholic University of America Press, 2008.

Heisterbach, Caesarius of. The Dialogue on Miracles. Edited by G. G. Coulton. Vol. 2. New York: George Routledge \& Sons, 1929.

Herzman, Ronald B., Graham Duke, and Eve Salisbury, eds. "Athelston.” Four Romances of England, 1999.

Hincmar, Rachel Stone, and Charles West. The Divorce of King Lothar and Queen Theutberga: Hincmar of Rheimss De Divortio. Manchester: Manchester University Press, 2016.

Hyams, Paul R. King, Lords and Peasants in Medieval England: the Common Law of Villeinage in the Twelfth and Thirteenth Centuries. Oxford: Oxford University Press, 1980.

Kerr, Margaret H., Richard D. Forsyth, and Michael J. Plyley. "Cold Water and Hot Iron: Trial by Ordeal in England." Journal of Interdisciplinary History22, no. 4 (1992): 573-95.

Leeson, Peter T. “Ordeals.” The Journal of Law and Economics55, no. 3 (2012): 694.

Lyons, Agobard of. Liber Adversus Legem Gundobadi, n.d. 
Lyons, Agobard of. “De Divinis Sententiis.” Edited by Courtney M. Booker, 2015.

Papp Kamali, Elizabeth. "Trial by Ordeal by Jury in Medieval England, or Saints and Sinners in Literature and Law." Vengeance and Law in the Middle Ages: Essays in Honor of William Ian Miller, n.d.

Radding, Charles M. "Superstition to Science: Nature, Fortune and the Passing of the Medieval Ordeal.” The American Historical Review 84, no. 4 (October 1979): 945-69.

Strassburg, Gottfried von. Tristan. Translated by A.T. Hatto. Baltimore: Penguin Books, 1960.

Whitman, James Q. The Origins of Reasonable Doubt: Theological Roots of the Criminal Trial. New Haven: Yale University Press, 2008. 